\title{
Consumption Expenditures as Key Drivers of Economic Growth and Manufacturing Expansion in Nigeria
}

\author{
Olumuyiwa Olamade \\ Department of Economics, Caleb University Imota, Lagos State, Nigeria
}

\begin{abstract}
This study has two goals: first, to investigate the effects of private and government consumption expenditures as well as imports and exports on economic growth in Nigeria. Second, to analyse the implications of these expenditures for manufacturing sector expansion given the special growth-enhancing properties of manufacturing as articulated in the theoretical and empirical literature. Our estimations of the three models specified for the study are based on the Nigeria time-series data from the World Development Indicators database between 1981 and 2019 using Pesaran's ARDL regression methodology after testing the trend properties of the series. The validity and reliability of regression results were certified by the regression diagnostics.Our findings support significant positive effects of private consumption expenditure and exports on economic growth while government consumption expenditure and imports exert a significant negative impact on growth. These two expenditures that grow the economy neither significantly expand nor decrease manufacturing as the positive impacts of private consumption expenditure and the negative impacts of exports were insignificant. The negative effects on manufacturing of government consumption expenditure and imports were not significant. However, economic growth was found to significantly expand manufacturing activities. We conclude that over two-thirds of Gross Domestic Product expenditures constitute a leakage from the economy being insignificant to drive manufacturing expansion. The resultant loss of the flow of growth-enhancing externalities from manufacturing to other sectors of the economy may constrain future economic growth or cause the economy to grow in an unsustainable manner.
\end{abstract} Keywords: consumption, government expenditure, economic growth, manufacturing, exports.

DOI: $10.7176 / \mathrm{DCS} / 11-1-05$

Publication date: January $31^{\text {st }} 2021$

\section{Introduction}

The long-run analysis of economic growth has predominantly followed in the steps of the mainstream growth theory in which aggregate demand is a short-run consideration and of no relevance in the long-run. Supply-side factors are the main determinants of the rate at which economies grow under the assumption that the economy is always at full employment and all saving is automatically invested. Deficiency in aggregate demand and the associated unemployment is solved in the long-run by the self-balancing mechanisms of the market working through labour and asset market adjustments or government macroeconomic policy. Keynesian macroeconomics, on the other hand, asserts that aggregate demand is the most important driver of economic growth such that inadequate aggregate demand could lead to prolonged periods of high unemployment. To the Keynesians, an economy's total output of goods and services $(\mathrm{Y})$ is the sum of four components of aggregate demand; consumption (C), investment (I), government purchases (G), and net exports (X-M). Economic growth results from a sustained increase in these four components and macroeconomic imbalances resulting from the business cycle are corrected through government policy intervention targeted at restoring full employment and price stability as the free market lack mechanisms for self-balancing propounded in the mainstream growth theory.

The great depression of the 1930s challenged the efficacy of the mainstream growth theory prescriptions as it failed to find the causes of the great depression as well as provide an adequate policy direction to reboot production and employment. Keynesian macroeconomics branding aggregate demand stimulation and government policy intervention thus came into prominence. However, the concurrence of slow growth and inflation suffered by many advanced countries in the 1970s queried Keynesian economics as a dominant economic thought giving rise to monetarism. A resurgence in Keynesian economics came with the global financial crisis of 2007-2008 as it provided many governments with the theoretical underpinnings of economic policies in response to the crisis (Jahan, Mahmud \&Papageorgiou, 2014). It is in the light of this resurgence that this study examines the influence of aggregate demand on Nigeria's economic growth. Specifically, we will examine the relative strength of private consumption expenditures, government purchases, and net-exports components of the aggregate demand as drivers of economic growth, on the one hand, as well as investigate the implications of the result obtained for the manufacturing sector growth on the other hand. On the latter, we specifically want to find out if the expenditures that drive growth are equally good for manufacturing sector expansion.

The rest of the paper is structured to present a review of the extant literature on economic growth vis a vis the aggregate demand, and the dynamics of economic growth and manufacturing sector development in section two. The methodology of the study will be set out in section three while econometrics tests and analyses are performed, reported, and discussed in section four. Conclusions and policy recommendations are made in section five of the 
study.

\section{Literature Review}

Systematic economic analysis from the classical economists has investigated the dynamic forces which determine the sources, forms, and effects of economic growth. Both Smith (1776) and Ricardo (1871) identified capital accumulation which brings about higher labour productivity and hence output per worker as an important source of economic growth. Ricardo besides considered the important role of technical progress as a driving force of economic growth. Given the long history of economic growth theories and models, Greiner (2011) identified some robust empirical regularities that have been observed to characterise economic growth from the 1960s to the modern economies of the $21^{\text {st }}$ century. These regularities have been well confirmed in the advanced economies, the rapidly advancing economies of South-East Asia, and to a lesser degree in Africa. They include:

- a continued increase in the amount of capital per worker,

- a steady capital-output ratio over long a time,

- a slightly declining rate of return as an economy evolves through the long term as opposed to the previously held assumption of a steady rate of return to capital which exceeds the long-term rate of interest,

- a high correlation between the share of profits in income and the share of investment in output and a steady share of wages and physical capital in national income,

- considerable differences in the rate of growth of labour productivity and total output in different economies,

- a fast rate of structural transformation from the agricultural sector to the industrial sector and later to the services sector,

- the increasing role of technological change as economies grow,

- the increased significance of governments in the process of economic growth

- the reduced dependence on natural resources,

- the rising importance of foreign trade, and

- the increased role of human capital formation.

Economic growth theories from which the outlined regularities were drawn can broadly be divided into two prominent thought threads; the exogenous and endogenous (new) growth theories that constitute the mainstream theory of growth. The exogenous growth theory of Solow (1956) and Swan (1956) assumes that long-run economic growth rate can be explained by the growth rate of total factor productivity which is determined by the rate of technological progress. The rate of technological progress is in turn dependent on a scientific process that is separate from and independent of economic forces. Thus, the long-run growth rate is exogenously determined from outside the economic system (Howitt, 2008). Endogenous growth theory which began to emerge in the 1980s, on the other hand, attempts to uncover the private and public sector choices within an economic system that cause the rate of economic growth to vary across countries. Technological progress, therefore, is endogenous as it depends on the public and private decision to invest in technology development and diffusion. Barro (1996) argued that differences in economic growth rates among countries result from differences in propensity to save, access to technology, and government policy such that a government that allocates increased expenditure to attenuate market distortions, enforce property rights, provide infrastructural services, and ensure better financial markets generates efficiencies that translate into economic growth. By endogenising the drivers of growth the theory allows policy and institutional factors to shape economic growth (Bassanini\&Scarpetta, 2001).

Most macroeconomic analysis models determine the short-run performance of an economy at the intersection of the aggregate demand and supply curves, however, both the exogenous and endogenous growth models depart from this and implied that the growth rate of income per capita in the long-run equilibrium is a function of several supply factors and gives no consideration for the Keynesian problem of aggregate demand. In the long-run, the problem is solved by the invisible hand of the free market working through labour and asset market adjustments, or by the visible hand of government macroeconomic policy (Dutt, $2006 \& 2010$ ). The great depression of the 1930s puts to the test the self-balancing market mechanisms tenet of the neoclassical school in its inability to either explain the causes of the global economic depression or to provide an adequate public policy solution that will stimulate production and employment. Consequently, policy-makers sought relief in Keynes's assertion that aggregate demand is the most important growth factor in an economy and that free markets have no self-balancing mechanisms that lead to full employment (Jahan, Mahmud \&Papageorgiou, 2014). The success of Keynesian prescriptions in tackling the great depression and the wide adoption by most countries of a mixed economy guided mainly by the private sector but partly operated by the government and the realization that each component of the gross domestic product contributes in varying degrees to the level and distribution of output and employment opened a new vista in empirical research to investigate the nexus between economic growth and the components of aggregate demand.

Consumer spending decisions about what to buy, how much to buy, and when to buy from the myriad of goods and services produced in an economy is a major determinant of how much of which goods and services 
ultimately will be produced and where employment is directly or indirectly created in the economy (Toossi, 2002). Thus, an economy's industrial composition, the direction of structural change, and the reallocation of employment and capital across industries are intrinsically linked to consumer spending (Krueger, 2008; Ciarli et al 2010). Private consumption expenditures measure consumer spending on goods and services and account for between half and two-thirds of Gross Domestic Product (GDP) in most countries. Consumer spending accounts for a majority of spending in all advanced nations and tends to be disproportionally higher in poorer countries. Private consumption expenditures have been the dominant source of economic growth in the United States in recent decades growing faster than the rest of the economy and the GDP (Emmons, 2012). Consumption-led economic growth corresponds to periods during which private consumption expenditures grow more quickly than GDP either in nominal or real terms (Kharroubi\&Kohlscheen, 2017). Many economists have provided theoretical evidence against the sustainability of consumption-led growth. Lingle (2001) argued in favour of reserve causality that consumption expansion is a result of economic growth and not its main driver as consumption only creates an artificial and temporary sense of increased prosperity. Kharroubi\&Kohlscheen (2017) using US data empirically demonstrated that economic growth is systematically weaker when led by consumption. More importantly, consumption-led growth points to future growth slowdownsparticularly if consumption is fueled by growing external imbalances and rising household debt burdens. A growing body of literature, including Mian, Rao, \& Sufi (2013), Juselius et al (2016), and Drehmann, Juselius, \&Korinek (2017) provided empirical evidence that points to the danger for future economic growth slow-down arising from a debt-driven consumption expansion.

Extensive academic research has focused on the impact of government spending on economic growth. A very big government sector may have negative spillover effects on the economy due to the financing of government spending by raising taxes, borrowing, and/or printing money. On the other hand, a very small or zero government spending may engender very limited economic growth due to difficulties in providing public goods. There thus exists an optimal level of government spending that maximises economic growth (Asimakopoulos\&Karavias, 2015). The empirical literature is yet inconclusive. Several empirical works found a negative relationship between government spending and growth (Barro 1989, 1990, 1991; Dar \&AmirKhalkhali, 2002; Chen \& Lee, 2005; Guseh, 2007), whereas other studies found a positive relationship (Grossman, 1988; Carr, 1989; Bose, Hague, \& Osborn, 2007; Romero-Avila \&Strauch, 2008). However, a good number of researchers supports an inverted "U-shaped" curve relationship, also known as the BARS curve after Barro (1989), Armey (1995), Rahn and Fox (1996), and Scully (1995), between government spending and economic growth according to which increase of government spending is beneficial up to a certain threshold and beyond that level the impact on growth is negative (Asimakopoulos\&Karavias, 2015).

The question of whether trade causes growth has a long history and far from being settled. Whilst some studies produce evidence that international trade positively affects economic growth in developed countries, others (e.g. Kim, 2011) fail to empirically prove such a positive effect in developing countries. However, a large body of theoretical and empirical studies supports a positive relationship between trade and economic growth in both developed and developing countries, although there are controversies regarding the data and methodology of analysis. To assuage the methodological concerns, Frankel \&Romer (1999) and Irwin \&Tervio (2000) controlled for the endogeneity of trade and both obtained a positive relationship between trade and economic growth. Lewer and Van den Berg (2013) examined whether the statistically significant trade-growth relationship found by the cross-country empirical studies undertaken in the 1990s was economically significant. They found the results were robust and consistent in terms of the coefficients across samples and the diverse statistical methodologies. In general, trade facilitates the distribution of the gains of globalization within and among nations (UNDP, 2012). The nexus of imports and economic growth can be established via both the demand and supply sides and could have off-setting effects. On the supply side, the importation of high-quality capital and intermediate goods that are not produced in the domestic market contributes to the diffusion of technology (Keller, 2001) and increase in the level of manufacturing productivity (Lee, 1995). If the process of product development necessary for international competitiveness is human-capital intensive (Grossman \&Helpman, 1989), trade can help accelerate economic growth in developing countries with low levels of human capital through access to a larger pool of global human capital (Romer, 1990). On the demand side, imports are seen as leakage and growth-constraining. Lim and Park (2007) argued that if GDP growth is always the source of finance for imports then they can constrain growth. For instance, increased imports may cause the import-substituting domestic industries to shrink thereby reducing investment and productivity, and ultimately limiting economic growth. Hence, Mishra (2012) is of the view that the empirical evidence on the nexus between imports and economic growth is rather mixed and inconclusive. In a disaggregated analysis, Burney (1996) and Were (2015) showed that the effects of exports differ by the level of development. Awokuse and Christopoulos (2019) in a study of five industrialised economies reported the diminishing impact of exports on economic growth thus establishing a threshold level beyond which export is not beneficial for economic growth. Whereas exports have a significant positive impact on economic growth in developed and developing countries, the impact is not significant for developing countries most of which are in Africa (Were, 2015). However, in a 1998 study of twelve Sub-Saharan Africa (SSA) countries by 
Onafowora\&Owoeye, the result found a significant positive effect of exports on economic growth with the conclusion that it was possible to stimulate growth through an outward-oriented growth strategy. Hameed, Igbal\& Devi (2012) and Sayef\& Mohamed (2019), using the Granger causal technique found a unidirectional causality from GDP to exports in Pakistan and Morocco, respectively. Bakari\&Tiba (2019) on the contrary reported that exports negatively affect economic growth.

Kaldor $(1966,1967)$ argued that sector and activity specificity is at the heart of cross-country differentials in development and growth rates and thus offered support for the key role of the manufacturing sector in economic growth. This role is attributed to the special growth-enhancing properties of manufacturing that trigger a process of cumulative causation that are not shared by other sectors. (Pacheco-López\&Thirlwall, 2013; Rocha, 2018). The manufacturing sector is presumed to serve the whole economy as a source of productivity growth and economies of scale, a vehicle to stimulate trade and internationalisation, and an engine for R\&D and innovation (Lavopa\&Szirmai, 2014; EPSC, 2015). In his first law, Kaldor posited that "manufacturing is the engine of growth" by which he advanced that the faster the rate of growth of the manufacturing sector the faster the rate of growth of the economy. Both empirical and theoretical evidence affirms the engine of growth hypothesis. Rodrik (2009) \&Szirmai (2012) established an empirical correlation between the degree of industrialisation or manufacturing intensity and the level of per capita income in developing countries. In cross-section comparisons, the relationship between per capita income and the share of manufacturing in the GDP can be described not by a linear but by an inverted U-shaped curve. Low shares of manufacturing in the GDP were associated with low and high-income economies with an intermediate level of income economies having a high share of manufacturing GDP (Rodrik, 2009). While Europe is re-industrialising by targeting increased R\&D investments through manufacturing (European Commission, 2014), industrialising developing countries have used intensive manufacturing as a catchup strategy. Manufacturing with its higher level of capital and investment takes on the central role of absorbing technology as well as creating strong externalities of knowledge flows to other sectors. These vital characteristics make the manufacturing sector crucial for developing economies as a means of achieving income convergence with developed economies ( $\mathrm{Su} \&$ Yao, 2016). However, recent studies are concluding that although the manufacturing sector may have played an important role in income growth, especially for catch-up strategies used by developing countries, the size of the manufacturing sector has become a more difficult route for economic growth since the early 1970s (Szirmai and Verspagen, 2015). This has been attributed to the growing share of services in household consumption baskets that encouraged service-led growth at higher levels of income (Szirmai, 2012; Coad \&Vezzani, 2017). Since spending on goods and services whether by domestic consumers, government and non-residents is a key determinant of what goods and services are produced in a country, this study will attempt to investigate the appropriateness of the pattern of consumption spending for manufacturing sector expansion given the growth-enhancing properties of the sector.

\section{Methodology}

\subsection{Data and model specifications}

The import of this paper is to determine the relative strength of the various consumption expenditures to drive economic growth and to investigate the influence of the observed expenditure pattern for the manufacturing output expansion. Nine variables were identified to provide adequate information to satisfy the objectives of the paper. Annual data series were obtained from the World Development Indicators database for the variables measured current local currency units. The time series covers 1981 to 2019 for which the database provides unbroken information. Table 1 provides a list of the variables and their operational definition in their natural logarithm. Table 1: Variables definition

\begin{tabular}{|l|l|}
\hline Variable & \multicolumn{1}{|c|}{ Definition } \\
\hline$y$ & GDP per capital \\
\hline$P C E$ & Private consumption expenditures for final consumption expenditures of households and NPISHs \\
\hline$G C E$ & General government final consumption expenditures \\
\hline$E X P$ & Exports of goods and services \\
\hline$I M P$ & Imports of goods and services \\
\hline$N E X$ & Net exports obtained as the difference of the logs of exports and imports of goods and services \\
\hline$D C E$ & $\begin{array}{l}\text { Domestic consumption expenditures for the sum of private and general government final } \\
\text { consumption expenditures }\end{array}$ \\
\hline$B D M$ & Broad money supply \\
\hline$M V A$ & Manufacturing value-added \\
\hline
\end{tabular}

Based on the variables, we specify three models as follows:

Model 1 examines the power of domestic consumption expenditures and net foreign expenditures on economic growth. The model seeks to weigh the relative power of the domestic market and the external sector to influence economic growth. Thus, $D C E$ and $N E X$ were regressed on $y$ at time $t$ with $B D M$ as a control. Model 1 is specified as: 


$$
Y_{\mathrm{t}}=6_{0}+6_{1} D C E_{\mathrm{t}}+6_{2} N E X_{\mathrm{t}}+6_{3} B D M_{\mathrm{t}}+\varepsilon_{\mathrm{t}}
$$

Equation (i) is disaggregated in Model 2 to investigate separately the power of each of the two components of domestic consumption expenditures, and the external sector. BDM here also serves as a control variable. Model 2 is specified as:

$$
Y_{\mathrm{t}}=\alpha_{0}+\alpha_{1} P C E_{\mathrm{t}}+\alpha_{2} G C E_{\mathrm{t}}+\alpha_{3} E X P_{\mathrm{t}}+\alpha_{4} I M P_{\mathrm{t}}+\alpha_{5} B D M_{\mathrm{t}}+\mu_{\mathrm{t}}
$$

Equation (ii) without the control variable is regressed against manufacturing value-added at time $t$ to check the fit of both economic growth and the consumption categories for manufacturing output expansion. We expect a priori, that manufacturing output will respond positively to economic growth and the consumption categories that spur economic growth. Model 3 is specified as below:

$$
M V A_{\mathrm{t}}=\mathrm{g}_{0}+\mathrm{g}_{1} Y_{\mathrm{t}}+\mathrm{g}_{2} P C E_{\mathrm{t}}+\mathrm{g}_{3} G C E_{\mathrm{t}}+\mathrm{g}_{4} E X P_{\mathrm{t}}+\mathrm{g}_{5} I M P_{\mathrm{t}}+3 \mathrm{t}
$$

Where $\sigma_{0}, \alpha_{0}$, and $\varrho_{0}$ are the intercepts; $\sigma_{\mathrm{t}}, \alpha_{\mathrm{t}}$, and $\varrho_{\mathrm{t}}$ are slope coefficients, and $\varepsilon_{\mathrm{t}}, \mu_{\mathrm{t}}$, and ${ }_{3 \mathrm{t}}$ represent the innovations of the regression models.

\subsection{Tests of data properties}

The empirical characteristics of many econometrics time series are not consistent with the regression requirement that their mean and variance be equal over time, as such, the time series must be tested for stationarity. A variable is non-stationary if its mean and variance are not equal, and will produce a spurious regression. We use the Augmented Dickey-Fuller (ADF) and the Phillips-Perron (PP) tests to check for stationarity. We report in Table 2 the probabilities of the test statistic from each of the two tests showing the variables as stationary at either level or first difference at the conventional levels of significance. Both test the null hypothesis that a unit root is present in an autoregressive model of a given time series and as such the process is non-stationary.

Table 2: Test of stationarity

\begin{tabular}{|l|c|c|c|c|}
\hline \multirow{2}{*}{ Variables } & \multicolumn{2}{|c|}{ ADF } & \multicolumn{2}{c|}{ PP } \\
\cline { 2 - 5 } & $I(0)$ & $I(1)$ & $I(0)$ & $I(1)$ \\
\hline$y$ & 0.6445 & $0.0188^{* *}$ & 0.7808 & $0.0222^{* *}$ \\
\hline$p c e$ & $0.0488^{* *}$ & - & $0.0488^{* *}$ & - \\
\hline$g c e$ & 0.8283 & $0.0000^{*}$ & 0.8286 & $0.0000^{*}$ \\
\hline $\exp$ & 0.3694 & $0.0000^{*}$ & 0.4981 & $0.0000^{*}$ \\
\hline$i m p$ & 0.7631 & $0.0001^{*}$ & 0.7628 & $0.0002^{*}$ \\
\hline$n e x$ & $0.0035^{*}$ & - & $0.0037^{*}$ & - \\
\hline$d c e$ & $0.0611^{* *}$ & - & $0.0737^{* *}$ & - \\
\hline$b d m$ & 0.7402 & $0.0194^{* *}$ & 0.8480 & $0.0326^{* *}$ \\
\hline$m v a$ & 0.8495 & $0.0123^{* *}$ & 0.8750 & $0.0125^{* *}$ \\
\hline
\end{tabular}

$*, * *, * * *$ respectively indicate $0.01,0.05$ and 0.10 significant levels.

The ADF and PP are both left-tail tests and certify a variable as stationary, at level or first difference, if the absolute value of the test statistic is significant at the conventional levels of significance and greater than the critical values.

\subsection{Selection of the method of analysis}

The appropriate method of analysis is selected based on the result of stationarity tests. Each of the three models specified for estimation comprises of level and first difference stationary variables. Using the Ordinary Least Squares (OLS) method to estimate the models will give wrong results because the non-equal mean and variance, as well as trending characteristics of the time series variables, make them violate the Classical Linear Regression Model (CLRM) assumptions. Thus, we will proceed to use the ARDL bounds test to estimate the models, if the variables are cointegrated. The F-Bounds test of the ARDL framework will be used to check the existence of a long-run relationship of the variables for each model. A decision is made for the existence of a long-run relationship of variables if the F-Bounds test statistic is superior to the upper-bound value at a $5 \%$ level of significance. The existence of a long-run relationship is presumed if the coefficient of the cointegration equation of the ECM regression is negative and significant. The results are reported in Table 3. 
Table 3: Test of cointegration

\begin{tabular}{|l|l|c|c|c|c|}
\hline \multirow{2}{*}{ Model 1 } & Test Statistic & Value & Significance & $I(0)$ & $I(1)$ \\
\hline \multirow{2}{*}{ CointEq(-1)* } & F-Statistic & 9.372422 & $2.5 \%$ & 3.15 & 4.08 \\
\cline { 4 - 6 } & & & $1 \%$ & 3.65 & 4.66 \\
\cline { 3 - 6 } & & & & - & - \\
\hline \multirow{2}{*}{ Model 2 } & F-Statistic & 11.10308 & $2.5 \%$ & 2.7 & 3.73 \\
\cline { 3 - 6 } & & & $1 \%$ & 3.06 & 4.15 \\
\hline \multirow{2}{*}{ CointEq(-1)* } & Coefficient & Probability & - & - & - \\
\cline { 2 - 6 } & -0.842045 & 0.0000 & - & - & - \\
\hline \multirow{2}{*}{ Model 3 } & F-Statistic & 3.738426 & $5 \%$ & 2.39 & 3.38 \\
\cline { 3 - 6 } & & & $2.5 \%$ & 2.7 & 3.73 \\
\hline
\end{tabular}

The satisfaction of the conditions for the F-statistic and the coefficient of the cointegration equation will be required to assert the existence of a long-run relationship of the variables. The value of the F-Statistic is greater than the upper-bound value in each model. Similarly, the coefficients of the cointegration equations are all negative and significant. Variables cointegration are concluded for the three models and we decide for ARDL regression analysis for the specified models.

\subsection{Diagnostics}

Results of the ARDL regressions to determine how consumption expenditures influence economic growth in the long-run and the implication of the pattern of consumption expenditures for manufacturing output expansion are deemed meaningful and provide a reliable guide for policy decisions if the standard classical regression assumptions are satisfied. To guarantee the reliability of our estimated parameters, a battery of diagnostic tests will be conducted. First, we will examine how perfectly our models predict the dependent variables by reporting both the $\mathrm{R}^{2}$ and the adjusted $\mathrm{R}^{2}$. The closer to 1.00 the better the models predict the observed data. We will test the overall significance of the regression model by reporting the Prob(F) which tests the probability for the full model that all of the regression coefficients are zero. The closer the Prob(F) is to 0.00 the higher the probability that at least some of the regression parameters are non-zero and the independent variables are not purely random relative to the dependent variable. The Breusch-Godfrey, Breusch-Pagan-Godfrey, and Jarque-Bera tests will respectively check the regression residuals for serial correlation, heteroscedasticity, and normality. Finally, we test the stability of the parameters with the CUSUM and CUSUM of squares tests. While the former identifies systematic changes in the regression coefficients, the latter detects sudden changes from the constancy of the regression coefficients. Diagnostics results are presented in Table 4.

Table 4: Diagnostics

\begin{tabular}{|l|c|c|c|}
\hline & Model 1 & Model 2 & Model 3 \\
\hline R-Squared & 0.999360 & 0.999880 & 0.997560 \\
\hline Adjusted R-Squared & 0.999011 & 0.999687 & 0.996972 \\
\hline Prob(F-Statistic) & 0.000000 & 0.000000 & 0.000000 \\
\hline Breusch-Godfrey Serial Correlation LM test & 0.1334 & 0.4005 & 0.4500 \\
\hline Breusch-Pagan-Godfrey Heteroskedasticity test & 0.6174 & 0.3310 & 0.0632 \\
\hline Normality test: Jarque-Bera Probability & 0.987001 & 0.996765 & 0.886660 \\
\hline
\end{tabular}

The CUSUM plots for the three models are displayed in Figure 1. Results of the residual diagnostic tests are satisfactory (greater than $5 \%$ ) and affirm that our models are adequate and well treated. Both the $\mathrm{R}^{2}$ and the adjusted $\mathrm{R}^{2}$ are greater than $90 \%$. The Prob(F) in each model asserts the certainty of the estimated parameters being non-zero. The estimated parameters are stable over the sample period as the plots of the CUSUM and CUSUM of squares fall within the $5 \%$ confidence intervals of the parameter stability. 

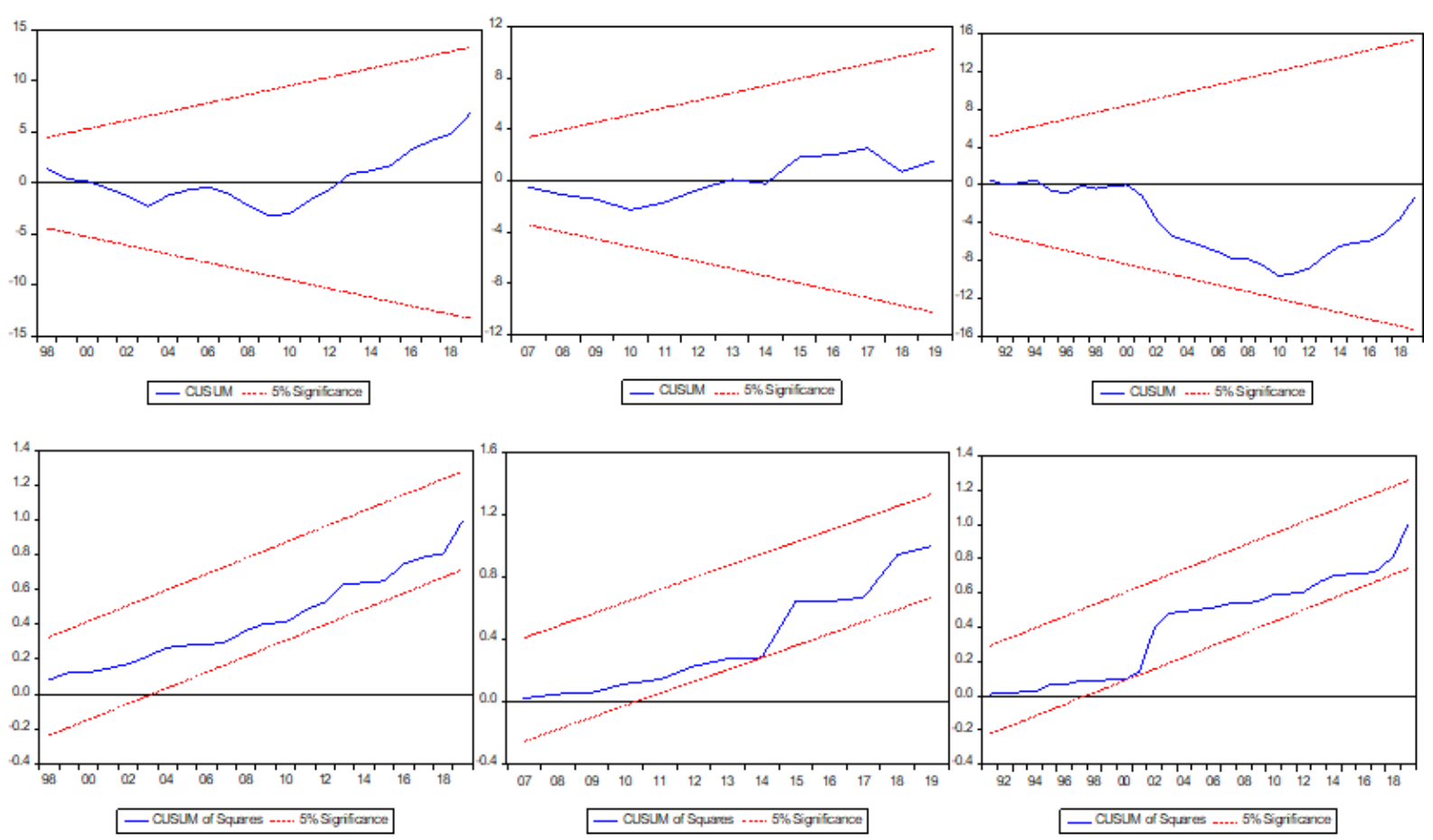

Model

Model 2

Model 3

Figure 1: CUSUM and CUSUM of squares test of parameter stability

\section{Results}

Having satisfied the requirements for valid inference as evidenced in the processes reported in sections $3.2-3.4$, we now report and discuss the regression results for the three models.

Table 5: Model 1 ARDL Long Run Form

\begin{tabular}{crrrr}
\hline \hline Variable & Coefficient & Std. Error & t-Statistic & Prob. \\
\hline \hline DCE & 1.023758 & 0.076179 & 13.43885 & 0.0000 \\
NEX & 0.249602 & 0.064648 & 3.860951 & 0.0008 \\
BDM & -0.228152 & 0.077598 & -2.940168 & 0.0076 \\
C & -12.58459 & 0.271019 & -46.43430 & 0.0000 \\
\hline \hline
\end{tabular}

$\mathrm{EC}=\mathrm{Y}-(1.0238 * \mathrm{DCE}+0.2496 * \mathrm{NEX}-0.2282 * \mathrm{BDM}-12.5846)$

Contrary to the neoclassical growth thesis, the result displayed in Table 4 from our Model 1 showed that demand-side factors are relevant to the long-run growth performance of an economy. Both domestic consumption expenditures and net exports are significantly positive to economic growth in Nigeria. a one percentage point increase in DCE increase per capita income level by slightly more than one percentage point. The significant positive effect of net export on per capita income level is not as strong as domestic consumption spending. Per capita income grows by about a quarter percentage point for every percentage point increase in net exports. The significant negative coefficient of broad money reflects the impact of rapidly expanding money supply on the economy via rising inflation level, but not strong enough to reverse the significant positive effects of the two demand-side factors. The intercept is negative and significant, an indication that per capita income level falls significantly in the face of deficiency in consumption spending. Thus, consumer spending is a growth factor in the Nigerian economy.

Now we examine in more detail the effect of specific factors in the domestic consumption and net export spending on the level of per capita income. We will interpret the regression result of Model 2 for this purpose. 
Table 6: Model 2 ARDL Long Run Form

\begin{tabular}{crrrr}
\hline \hline Variable & Coefficient & Std. Error & t-Statistic & Prob. \\
\hline \hline PCE & 0.828413 & 0.083651 & 9.903185 & 0.0000 \\
GCE & -0.108393 & 0.047234 & -2.294804 & 0.0390 \\
EXP & 0.209823 & 0.070140 & 2.991493 & 0.0104 \\
IMP & -0.276053 & 0.111967 & -2.465480 & 0.0284 \\
BDM & 0.185144 & 0.082329 & 2.248824 & 0.0425 \\
C & -13.81014 & 0.573392 & -24.08500 & 0.0000 \\
\hline \hline
\end{tabular}

$\mathrm{EC}=\mathrm{Y}-(0.8284 * \mathrm{PCE}-0.1084 * \mathrm{GCE}+0.2098 * \mathrm{EXP}-0.2761 * \mathrm{IMP}+0.1851$

*BDM -13.8101)

When domestic consumption expenditure was disaggregated into private and government consumption expenditures, the strong and significant positive effective effect of household spending came to the fore. Table 6 shows that private consumption spending is a powerful factor in growing per capita income. Each ten percentage point increase in consumers' spending increases per capita income level by eight percentage points. This implies that consumer spending account for $80 \%$ of per capita income growth in Nigeria. Economic growth in Nigeria can thus be termed consumption-led, according to Kharroubi\&Kohlscheen (2017) implies that in real terms private consumption spending has been growing faster than the GDP. Government consumption spending is significant but negative in its effect on per capita income. Explaining this outcome in terms of the inverted "U" shaped BARS curve, government consumption spending in Nigeria may have passed the threshold for a significant and positive relationship with economic growth. This result is consistent with the findings of Nurudeen\& Usman (2010) and Onifade, Çevik, Erdoğan, et al (2020) that reported a significant negative effect of government recurrent expenditure on economic growth. The positive and significant effect of the external sector on per capita income growth is driven primarily by the exports of goods and services. While export is positive and significant, import is negative and significant implying that, overall, a dollar of export enhances per capita income level more than an equivalent import decreases per capita income level. The demand-side effect of import as leakage is here seen to out-weigh its supply-side effect as a means of access to and diffusion of new technologies which enhances labour productivity.

We have empirically shown that different types of consumption expenditure exert a different effect on the level of per capita income, and hence economic growth. While consumer spending and export are growthenhancing, government consumption spending and import work the opposite. Our attention now turns to the investigation of what the different consumption spending portends for domestic manufacturing. Is what a sauce for economic growth sauce for manufacturing? We will speak to Table 7 in this regard.

Table 7: Model 3 ARDL Long Run Form

\begin{tabular}{ccccc}
\hline \hline Variable & Coefficient & Std. Error & t-Statistic & Prob. \\
\hline \hline Y & 0.977855 & 0.463041 & 2.111811 & 0.0434 \\
PCE & 0.366671 & 0.291242 & 1.258991 & 0.2181 \\
GCE & -0.230016 & 0.084372 & -2.726210 & 0.0108 \\
EXP & -0.017710 & 0.175587 & -0.100861 & 0.9204 \\
IMP & -0.100391 & 0.197350 & -0.508693 & 0.6148 \\
C & 15.51911 & 5.311612 & 2.921733 & 0.0067 \\
\hline \hline
\end{tabular}

$\mathrm{EC}=\mathrm{MVA}-(0.9779 * \mathrm{Y}+0.3667 * \mathrm{PCE}-0.2300 * \mathrm{GCE}-0.0177 * \mathrm{EXP} 01-0.1004$

$*$ IMP + 15.5191)

Manufacturing value added positively responds to a growing level of per capita income in the long-run. A ten percentage point increase in per capita income increases manufacturing value-added by over nine percentage points. Sustained economic growth thus is a key contributing factor to manufacturing expansion in Nigeria. Consumers spending though a powerful driver of income growth is not a significant determinant of manufacturing growth. Consumers spending having a positive but insignificant relationship with manufacturing output expansion may indicate that private consumption expenditure works indirectly to impact manufacturing through economic growth. Having a situation such as we observe in this result threatens manufacturing as a growth strategy for Nigeria in the absence of policy interventions to redirect private consumption spending. Three key sources of threat are here identified based on empirical literature. First, giving that an economy's industrial composition and pattern of structural change is intrinsically linked to consumer spending on goods and services (Krueger, 2008; Ciarli, 2010), 
the relation of consumer spending to manufacturing value-added in Nigeria is an indication of a structural change away from manufacturing activities through which new technologies are absorbed and diffused for economy-wide productivity enhancement. The resulting loss of R \& D investments, labour productivity, and strong externalities of knowledge flow to other sectors associated with intensive manufacturing is a threat to sustainable economic growth. Second, between half and two-thirds of GDP are expended on goods not produced by the country's manufacturing sector and thus represent leakage from the economy, hence private consumption expenditure as a dominant source of economic growth is suspect if it drives away from local manufactures. If consumption expansion is a result of economic growth and not its main driver as argued by Lingle (2001), it follows that the domestic manufacturing sector shrinks as income grows and consumption consequently expands in favour of imports. Third, future economic growth is slowed down as the economy is burdened with growing external imbalance.

The coefficient of government consumption expenditure is negative and significant. An increase in government consumption expenditure by ten percentage points significantly reduces manufacturing value-added by almost a quarter of a percentage point. Government spending on wages and salaries, administrative expenses, and transfers are expected to increase the income available to consumers for the purchase of goods and services and thus may directly affect economic growth but indirectly affect manufacturing through consumer spending decisions. If consumer spending decisions, as well as government purchases of manufactures, are oriented towards foreign goods the local manufacturing sector may experience a significant decline as shown by the coefficient of government consumption expenditure. Export has a significant positive impact on economic growth which is not replicated in manufacturing as the coefficient is negative though insignificant. Import both negatively impacts economic growth and manufacturing expansion. Since we are dealing with the importation of goods and services which directly competes with local manufactures we expect a negative impact on manufacturing. Similarly, the negative impact on Nigeria's economic growth is reflective of the nature of imports. Previous studies found a significant positive effect on growth with the importation of high-quality capital and intermediate goods that are not produced locally. Where like in Nigeria manufactures export constitutes a small fraction of total export and imports competes directly with locally manufactured goods the results obtained in this study cannot be unexpected.

\section{Conclusion}

Consumer spending accounts for a majority of spending in all advanced economies and has been a dominant source of economic growth in some. Private and government consumption expenditures together account for more than two-thirds of the GDP in developing countries. Trade-in goods and services also constitute a sizeable percentage of the GDP. These expenditures not only tell on the growth pattern of the economy but also on the industrial composition and direction of structural change. This study has examined the effects of the various components of consumption expenditure on Nigeria's economic growth and the ensuing implications for the manufacturing sector. Three important findings were made by the study, first, manufacturing sector expansion significantly responds to economic growth and not any components of consumption expenditure. Second, private consumption expenditure which represents the largest share of GDP has no significant expansionary effect on the manufacturing sector. Third, government consumption expenditure and trade tend to stifle manufacturing expansion, though not significantly. Given these findings, government policy interventions are required to more tightly connect economic growth and manufacturing. Economic growth is more sustainable when driven by technology and investmentintensive sector like manufacturing. A diversified manufacturing sector able to meet the array of domestic consumer demands can both lock down a large share of national consumption expenditure and be sheltered from competing imports. With imports substantially limited to high-quality capital and intermediate goods not produced locally, the emerging strong and diversified manufacturing sector is better able to receive, adapt and replicate new technologies that are diffused to the rest of the economy as well as improve on export performance. A very strong domestic demand is a requirement to grow a diversified manufacturing sector and attract foreign direct investment which developing countries like Nigeria relied on for the acquisition of technology.

\section{References}

Asimakopoulos, S. \&Karavias, Y. (2015). The impact of government size on economic growth: a threshold analysis, Granger Centre Discussion Paper No. 15/02.

Awokuse, T. O. \&Christopoulos, D. K. (2019). Nonlinear dynamics and the exports-output growth nexus, Economic Modelling 26, 184-190.

Bakari, S. \&Tiba, S. (2019). The impact of trade openness, foreign direct investment and domestic investment on economic growth: New evidence from Asian Developing Countries. MRPA Paper 94489, https://mpra.ub.uni-muenchen.de/94489/1/MPRA_paper_94489.pdf

Barro, R. J. (1989). A cross country study of growth, saving, and government, NBER Working Paper 2855.

Barro, R. J. (1990). Government spending in a simple model of endogenous growth, The Journal of Political Economy 98 (5) 2: 103-125. 
Barro, R. J. (1991). Economic growth in a cross-section of countries, Quarterly Journal of Economics, 106, $407-$ 444.

Bassanini, A. \&Scarpetta, S. (2001). The driving forces of economic growth: panel data evidence for the OECD Countries, OECD Economic Studies, 33(2), 9-56.

Bose, N., Hague, M. E. \& Osborn, D. R. (2007). Public expenditure and economic growth: A disaggregated analysis for developing countries. The Manchester School, 75(5), 533-556.

Burney, N. A.(1996) Exports and economic growth: evidence from cross-country analysis, Applied Economics Letters, 3:6, 369-373, DOI: 10.1080/135048596356258

Carr, J. L. (1989). Government size and economic growth: a new framework and some evidence from cross-section and time-series data: comment, The American Economic Review, 79 (1): 267-271.

Chen, S. T. \& Lee, C. C. (2005). Government size and economic growth in Taiwan: a threshold regression approach, Journal of Policy Modelling 27, 1051-1066.

Ciarli, T., Lorentz, A., Savona, M., \& Valente, M. (2010). The effect of consumption and production structure on growth and distribution: a micro to macro model. . Metroeconomica, 61(1), 180-218. Doi: 10.1111/j.1467999X.2009.04069.x

Coad, A. \&Vezzani, A. (2017). Manufacturing the future: is the manufacturing sector a driver of R\&D, exports and productivity growth? JRC Working Papers on Corporate R\&D and Innovation No 06/2017.

Dar, A. A. \&AmhirKhalkhali, S. (2002). Government size, factor accumulation, and economic growth: evidence from OECD countries. Journal of Policy Modeling, 24, 679-692.

Drehmann, M., Juselius, M., \&Korinek, A. (2017). Accounting for debt service: the painful legacy of credit booms, BIS Working Papers No 645. https://www.bis.org/publ/work645.pdf

Dutt, A. K. (2006). Aggregate demand, aggregate supply and economic growth, International Review of Applied Economics, 20(3), 319-336. DOI: 10.1080/02692170600736094.

Dutt, A. K. (2010). Keynesian Growth Theory in the 21st Century, in Arestis, P., Sawyer, Malcolm (Eds.) 21st Century Keynesian Economics,Palgrave Macmillan UK.

Emmons, E. R. (2012). Don't expect consumer spending to be the engine of economic growth it once was, Federal Reserve Bank of St. Louis, https://www.stlouisfed.org/publications/regional-economist/january-2012/dontexpect-consumer-spending-to-be-the-engine-of-economic-growth-it-once-was

EPSC (2015). Integration of products and services: Taking the single market into the 21 st Century. EPSC Strategic Notes. Issue 7, 06 October.

European Commission (2014). For A European Industrial Renaissance. Communication from the Commission to the European Parliament, the Council, the European Economic and Social Committee and the Committee of the Regions, COM (2014) 14 final. https://eur-lex.europa.eu/legalcontent/EN/TXT/?uri=CELEX\%3A52014DC0014

Frankel, J.N. \&Romer, D. (1999). Does trade cause growth? American Economic Review. 89, 379-399.

Greiner, A. (2011). Models of Economic Growth, Vol. 2. https://www.eolss.net/Sample-Chapters/C02/E6-154-1300.pdf.

Grossman, G. M., \&Helpman, E. (1989). Product development and international trade, Journal of Political Economy, 97 (6), 1261-1283.

Grossman, P. J. (1988), Government and economic growth: a non-linear relationship, Public Choice 56: $193-200$.

Guseh, J. (2007). Government size and economic growth in developing countries: A political-economy framework. Journal of Macroeconomics, 19(1), 175-192.

Hameed, I., Iqbal, A., \& Devi, K. (2012). Relationship between Exports and Economic Growth of Pakistan, European Journal of Social Sciences, 32 (3), 453-460.

Howitt, P. (2008). Endogenous Growth, in The New Palgrave Dictionary of Economics, 2nd Edition, edited by Steven Durlauf and Lawrence Blume, New York: Palgrave Macmillan.

Irwin, D.A. \&Tervio, M. (2002). Does trade raise income? Evidence from the Twentieth Century. Journal of International Economics. 58, 1-18.

Jahan, S., Mahmud, A. S., \&Papageorgiou, C. (2014). What is Keynesian economics? Finance \& Development, 51(3).

Juselius, M., Borio, C., Disyatat, P \&Drehmannb, M. (2016). Monetary Policy, the Financial Cycle, and UltraLow Interest Rates, International Journal of Central Banking, 13(3), 55-89.

Keller W. (2001), Knowledge spillovers at the world technology frontier, NBER Working Paper, 8150.

Kharroubi, E. \&Kohlscheen, E. (2017). Consumption-led expansions, BIS Quarterly Review, Bank for International Settlements, March.

Kim, D., 2011. Trade, growth and income. Journal of International Trade \& Economic Development. 20 (5), 677709.

Krugman, P. (1980). Scale economies, product differentiation, and the pattern of trade. The American Economic Review, 70(5), 950. 
Lavopa, A. \&Szirmai, A. (2014). Structural modernization and development traps: an empirical approach. UNUMERIT Working Paper, 2014-076.

Lewer, J. J. \& Van den Berg, H. (2013). How large is international trade's effect on economic growth? Journal of EconomicSurveys, 17 (3), 363-396.

Lim, H., \& Park, S. (2007). Could imports be beneficial for economic growth: some evidence from Republic of Korea, ERD Working Paper Series No. 103, Asian Development Bank.

Lingle, C. (2001). Consumption can drive economic growth? FEE Foundation for Economic Education, fee.org/articles/can-consumption-drive-economic-growth/

Mian, A., Rao, K. \& Sufi, A. (2013). Household balance sheets, consumption, and the economic slump, Quarterly Journal of Economics, 128, pp. 1687-1726.

Mishra, P.K. (2012). The dynamics of the relationship between imports and economic growth in India. South Asian Journal of Macroeconomics and Public Finance, 1 (1), 57-79.

Nurudeen, A. \& Usman, A. (2010). Government expenditure and economic growth in Nigeria, 1970-2008: A disaggregated analysis. Business and Economics Journal, 4, 1-11.

Onafowora, O.A. \&Owoye, O. (1998). Can trade liberalization stimulate economic growth in Africa? World Development. 26 (3), 497-506.

Onifade, S. T., Çevik, S., Erdoğan, S., Asongu, S, \&Bekun, F. S. (2020). An empirical retrospect of the impacts of government expenditures on economic growth: new evidence from the Nigerian economy, Journal of Economic Structures, 9 (6), 1-13. https://doi.org/10.1186/s40008-020-0186-7

Ricardo D. (1996). Principles of Political Economy and Taxation, Amherst, NY, USA (first publication 1817).

Rocha, I. L. (2018). Manufacturing as driver of economic growth, PSL Quarterly Review, 71 (285), 103-138.

Rodrik, D. (2009). Growth after the Crisis. Harvard Kennedy School, Cambridge, MA.

Romer, P. M. (1990). Endogenous technological change, Journal of Political Economy, 98 (5), 71-102, Part 2.

Romer, P.M. (1994). The origin of endogenous growth. Journal of Economic Perspectives, 8(1), 3-22.

Romero-Avila, D. \&Strauch, R. (2008). Public finances and long-term growth in Europe: Evidence from a panel data analysis, European Journal of Political Economy 24(1), 172-191.

Sayef, B. \& Mohamed, M. (2019). The relationship between economic growth, exports and imports in morocco: an empirical validation based on var modeling techniques and causality in the meaning of Granger, Journal of Smart Economic Growth, 4 (3), 47-55.

Smith A. (1998). An Inquiry into the Nature and Causes of the Wealth of Nations, Oxford, Great Britain (first publication 1776).

Solow, R.M. (1956). A contribution to the theory of economic growth. Quarterly Journal of Economics, 70, 6594.

$\mathrm{Su}, \mathrm{D}$. \& Yao, Y. (2016). Manufacturing as the Key Engine of Economic Growth for Middle-Income Economies, ADB Working Paper Series No. 573.

Swan, T.W. (1956). Economic growth and capital accumulation. Economic Record, 32, 334-61.

Szirmai, A. (2012). Industrialisation as an engine of growth in developing countries, 1950-2005. Structural Change and Economic Dynamics, 23 (4), 406-420.

Toossi, M. (2002). Consumer spending: an engine for U.S. job growth, Monthly Labor Review, Office of Occupational Statistics and Employment Projections, Bureau of Labor Statistics, November. https://www.bls.gov/opub/mlr/2002/11/art2full.pdf

UNDP (2012). African Development Report. http://hdr.undp.org/sites/default/files/reports/240/ahdr_2012.pdf.

Were, M. (2015). Differential effects of trade on economic growth and investment: A cross-country empirical investigation, Journal of African Trade 2:1-2, 71-85, DOI: http://dx.doi.org/10.1016/j.joat.2015.08.002 